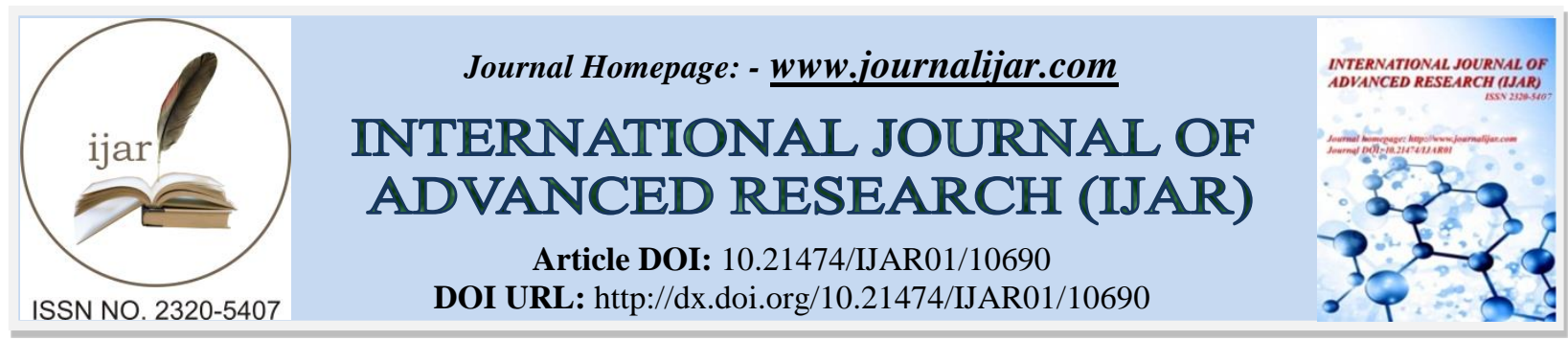

RESEARCH ARTICLE

\title{
DOES INTELLECTUAL CAPITAL PREDICT THE FINANCIAL PERFORMANCE OF THE INDIAN TEXTILE INDUSTRY?
}

Faizi Weqar and S.M. Imamul Haque

Department of Commerce of Aligarh Muslim University, Aligarh, 202002, India.

\section{Manuscript Info}

Manuscript History

Received: 17 January 2020

Final Accepted: 20 February 2020

Published: March 2020

Key words:-

Financial Performance, Intellectual

Capital, Productivity, Profitability,

Textile Industry, VAIC

\begin{abstract}
The main objective of this study is to examine the influence of intellectual capital (IC) on the financial performance of the Indian textile industry. The study employs the data of top 100 Indian textile companies for a period of ten years from 2009 to 2018. Value Added Intellectual Coefficient $\left(\mathrm{VAIC}{ }^{\mathrm{TM}}\right.$ ) methodology was employed for measuring the efficiency of IC. The results revealed that the efficiency of IC has a significant and positive relationship only with the profitability of the Indian textile industry; while among the components of IC, capital employed efficiency (CEE) is the most significant in improving the financial performance. Moreover, human capital efficiency (HCE) only helps in augmenting the profitability while structural capital efficiency (SCE) shows an inconsequential effect on profitability and productivity of the Indian textile industry.
\end{abstract}

Copy Right, IJAR, 2020,. All rights reserved.

\section{Introduction:-}

The success and prosperity of technologically advanced and knowledge-based business organisations of the world have bowed the attention of the researchers and academicians from tangible to intangible assets/capital. The intangible assets of the organisation embrace the knowledge, experience, talent, attitude, innovation, creativity, problem-solving ability, strong and healthy relationship with the stakeholders, systems, databases, patents, intellectual property, etc. These intangible assets are known as intellectual capital (IC). The conventional measure of financial performance is not compatible for the stakeholders, as it fails to capture and measure IC, making them illinformed regarding the factual position of the business organisation (Bontis, 2001; Joshi et al., 2013; Mehralian et al., 2012). IC can be employed as a tool to generate the value and augment the wealth of the organisation by improving the productivity of the employees and gain competitive advantage (Edvinsson \& Malone, 1997; Pulic, 1998; Stewart, 1997). Thus a direct influence of IC on the financial performance of the firm is anticipated (Ramandeep \& Narwal, 2016).

Additionally, IC is vital for the success of all types of industries, be it an agriculture, manufacturing or service industry. The difference is only based on the grade of involvement; several industries are high labour and capital intensive, while others are highly knowledge-intensive (Tiwari \& Vidyarthi, 2018). Researcher across the world, have explored the effect of IC in the process of value-creation and enhancement of the financial performance of the firm like Scafarto et al. (2016) in Italy, Sardo et al. (2018) in Portuguese, Riahi-belkaoui (2003) in the US, Afroz et al. (2018) in Bangladesh and Tiwari \& Vidyarthi (2018) in India. However, Smriti \& Das (2018) are of the view, that in India, the reporting and disclosure of IC are in the embryonic stage, which opens up new vistas for further 
exploration of the relationship mentioned above, i.e. IC and financial performance. Therefore, this study fills this void by taking the data of Indian textile industry into consideration.

Traditionally, the textile industry was not being thought of as a knowledge-intensive industry as it is characterised by the abundance of unskilled and cheap labour. By providing occupation to more than 45 million people directly in 2017-18, it is the second-largest source of employment in India after the agriculture sector (India, 2018). India is the leading producer of cotton, the second-largest producer of silk and rank number one in jute production in the world (India, 2018). In 2017-18, it contributed 2 per cent in India's GDP and 15 per cent in total export earnings of India amounting at the US $\$ 39.2$ (ibef, 2019). China, the leading exporter of textile and garments in the world, is now moving in the direction of the service-based economy and the prices of labour continue to rise, this will force many of the garment producers to move into the developing countries like India, Pakistan, Bangladesh, and Vietnam. Since China is stepping-back, this opens a stiff competition to become the world leader in the textile export, especially among the developing countries where cheap labour is accessible in profusion. India enjoys a competitive advantage over the other textile industry of the world in terms of production cost, skilled labour force and abundance of raw materials (India, 2018). Rising income level of the consumer, favourable demographic conditions and quality-oriented customers are also the few reasons for the foreign investors to invest in the Indian textile industry.

Furthermore, the nonconformity of a large number of industrial units in Bangladesh, one of the toughest competitor of India, opens-up an excellent opportunity for India, as the foreign industrialist perceive India as a cheap, safe and reliable option to invest. However, to capture the market, especially which is left by Bangladesh and China, we have to be very price competitive, improved quality, punctual in delivery, upgraded technology and improved working condition. Therefore, the Indian textile industry needs such type of strategic assets through which the above attributes can be achieved, and IC may act as such a strategic asset. In this backdrop, the data from the Indian textile industry has been employed for verifying the impact of IC, if any, on the Indian textile industry's financial performance.

This study addresses the lacuna from the literature by inspecting the effect of IC on the financial performance of the Indian textile industry. The empirical results will be useful for the national and international manufacturers and investors to analyse the component of IC that pushes the profitability and productivity of textile industry of India.

\section{Literature Review:-}

\section{Intellectual Capital (IC) and its classification:}

There are many definitions which are given by a large number of researchers and academicians across the globe. Among them, Edvinsson \& Malone (1997) defines IC as "knowledge that can be converted into value". IC embraces the "knowledge, information and technology of the organisation that adds value to the firm by the innovation, external relations, database and systems within an organisation" (Bontis, 1998; Edvinsson \& Malone, 1997). Stewart (1997) defines IC as a "packaged useful knowledge".

The most common classification of IC is given by Edvinsson \& Malone (1997) and Saint-Onge (1996). It classifies IC into "Human Capital, Relational Capital and Structural Capital".

Human capital is the accumulation of employee skills, knowledge, attitude, experience, talent and their problemsolving ability (Edvinsson \& Malone, 1997; Hashim et al., 2015; Zeglat \& Zigan, 2013).

Relational capital represents the capability of the business organisation to generate wealth and enhance its value through establishing the relationship with the outside parties such as the relationship with the customers, suppliers, shareholders, banks, financial institutions, government (Cabrita \& Bontis, 2008; Joshi et al., 2013; Sydler et al., 2013).

Structural capital is the intangible infrastructure erected by the employees of the organisation and includes copyright, trademark, patent, systems, database, models and process (Bontis et al., 2015; Nazari \& Herremans, 2007).

\section{IC and organisational financial performance:}

There are several studies, both in the developed and developing countries, which had checked the bearing of IC on the organisations' financial performance. For instance, a study on the Italian companies by Ginesti et al. (2018) 
found that the IC positively and considerably influenced the Italian firms' financial performance. Gogan et al. (2016) performed a study in the south-western region of Romania and found that financial performance and the IC have a significant and positive association in the drinking water distribution companies. Another study on the Bangladeshi textile industry by Afroz et al. (2018) reveals that human capital is insignificant while physical capital is essential for the entire indicators of financial performance used in the study (ROA, ROE and ATO) respectively. They also found that ROA and ROE are only positively influenced by structural capital.

Bontis et al. (2015) administered research on the Serbian hotel industry and found that the performance of the hotel industry was less influenced by IC than by the physical and financial capital. A study on the Australian listed firms by Clarke et al. (2011) also found that the physical capital more influences the performance of the sample firms than by the IC. Tan et al. (2007) report that the firms listed on the Singapore Stock Exchange are significantly associated with their IC. Weqar \& Haque (2020) found that the IC of Indian CPSEs only help in enhancing its productivity, while human capital is the strongest predictor in augmenting the financial performance of the Indian CPSEs.

Dzenopoljac et al. (2017) analysed 100 publicly traded Arab firms and found that physical capital and structural capital positively affects profitability and earning, while human capital mainly influences the market performance. A study on the local banks of Malaysia by Poh et al. (2018) reports that all three efficiencies of IC enhance the financial performance of the Malaysian banks. Xu \& Wang (2018) found that IC positively influences sustainable growth and financial performance in the manufacturing sector of Korea. Among the constituents of VAIC, relational capital, human capital and physical capital are positively associated with the growth and performance of the organisation.

Another study on the Indian banking industry by Singh et al. (2016) found that its efficiency of IC significantly and positively influences the profitability of the Indian banks. The study on the Indian banks was also conducted by the Mondal \& Ghosh (2012), and they found that both profitability and productivity is substantially and positively affected by the intellectual capital efficiency whereas ROE was not strongly influenced by the IC.

Ghosh \& Maji (2015) had checked the above relationship in Indian banking and electronic sector and reported that VAIC, HCE and CEE positively influence return on assets and market valuation. A study on the Indian textile and pharmaceutical firms by Pal \& Soriya (2012) shows that ROA is significantly affected by the intellectual capital while it fails to improve the market valuation and productivity of the Indian firms from both the sectors. Since the findings from these studies are mixed and different, and hence no concrete inference can be drawn from this. Therefore on this basis, the study formulated the following research objectives.

\section{Research Design and Methods:- \\ Objectives of the study:}

After an extensive review of the literature, the following research objectives are formulated:

To check the association between the components of the IC efficiency and the firms' financial performance.

To identify the components making the most significant contribution towards financial performance.

\section{Hypotheses of the study:}

For achieving the above research objectives, two main hypotheses have been framed. Each main hypothesis is divided into three sub-hypothesis. In this study, the authors predict the positive connection between the IC efficiency and its components (HCE, SCE and CEE) with the firms' financial performance as measured by profitability (ROA) and productivity (ATO). These hypotheses are as under:

H1:

There is a significant positive association between profitability (ROA) and intellectual capital efficiency (VAIC).

H1a:

There is a significant positive association between profitability (ROA) and human capital efficiency (HCE).

H1b:

There is a significant positive association between profitability (ROA) and structural capital efficiency (SCE).

H1c:

There is a significant positive association between profitability (ROA) and capital employed efficiency (CEE).

\section{H2:}


There is a significant positive association between productivity (ATO) and intellectual capital efficiency (VAIC). H2a:

There is a significant positive association between productivity (ATO) and human capital efficiency (HCE).

H2b:

There is a significant positive association between productivity (ATO) and structural capital efficiency (SCE).

H2c:

There is a significant positive association between productivity (ATO) and capital employed efficiency (CEE).

Sample size, data source and regression models:

The universe of the study comprises of all the textile firms of India. At present, there are more than 1500 medium and large scale textile firms in India. The study employs the secondary data of top 100 Indian textile companies based on the total assets of 2018 from the 'Prowess' database. The 'Prowess' database is maintained by the Centre for Monitoring Indian Economy (CMIE), and the period of study is ten years from 2008-09 to 2017-18. The data of top 100 textile companies have been taken, as by taking all the companies, the homogeneousness in the data may not have been attained.

The regression analysis constitutes four regression models. Model 1 investigates the association between the efficiency of IC (VAIC) and profitability (ROA) of the Indian textile industry after controlling for the firm size (LTA), physical capital intensity (pc) and Leverage (Lev). This model examines the hypothesis H1.

\section{Model 1:}

$\mathrm{ROA}_{\mathrm{it}}=\alpha+\beta_{1} \mathrm{VAIC}_{\mathrm{it}}+\beta_{2} \mathrm{LTA}_{\mathrm{it}}+\beta_{3} \mathrm{pc}_{\mathrm{it}}+\beta_{4} \mathrm{Lev}_{\mathrm{it}}+\varepsilon_{\mathrm{it}}$

Model 2 explores the liaison amid the constituents of VAIC and ROA of the textile firms of India. The three control variables are also included in the model. Model 2 explores the hypotheses H1a, H1b and H1c.

\section{Model 2:}

$\mathrm{ROA}_{\mathrm{it}}=\alpha+\beta_{1} \mathrm{CEE}_{\mathrm{it}}+\beta_{2} \mathrm{HCE}_{\mathrm{it}}+\beta_{3} \mathrm{SCE}_{\mathrm{it}}+\beta_{4} \mathrm{LTA}_{\mathrm{it}}+\beta_{5} \mathrm{pc}_{\mathrm{it}}+\beta_{6} \mathrm{Lev}_{\mathrm{it}}+\varepsilon_{\mathrm{it}}$

Model 3 inspects the connection between VAIC and productivity (ATO) of the Indian textile companies, after controlling for LTA, pc and Lev. This model scrutinises the hypothesis H2.

\section{Model 3:}

$\mathrm{ATO}_{\text {it }}=\alpha+\beta_{1} \mathrm{VAIC}_{\mathrm{it}}+\beta_{2} \mathrm{LTA}_{\mathrm{it}}+\beta_{3} \mathrm{pc}_{\mathrm{it}}+\beta_{4} \mathrm{Lev}_{\mathrm{it}}+\varepsilon_{\mathrm{it}}$

Model 4 explores the affiliation between the VAIC components and ATO of the Indian textile industry after controlling for the LTA, pc and Lev. This model examines the hypotheses H2a, H2b and H2c.

\section{Model 4:}

$\mathrm{ATO}_{\text {it }}=\alpha+\beta_{1} \mathrm{CEE}_{\mathrm{it}}+\beta_{2} \mathrm{HCE}_{\mathrm{it}}+\beta_{3} \mathrm{SCE}_{\mathrm{it}}+\beta_{4} \mathrm{LTA}_{\mathrm{it}}+\beta_{5} \mathrm{pc}_{\mathrm{it}}+\beta_{6} \mathrm{Lev}_{\mathrm{it}}+\varepsilon_{\mathrm{it}}$

Variables, its definition and measurement:

Dependent variables

For conducting the regression analysis, two dependent variables are employed, which are given below:

Return on Assets (ROA): It is employed as a profitability indicator for the firm. It had been employed in many previous studies such as Afroz et al. (2018); Al-Musali \& Ku Ismail (2016); Chan (2009a, 2009b); Ginesti et al. (2018) and Scafarto et al. (2016). It is the efficiency of the organisation in generating the profit by employing its resources. It is computed by dividing Profit After Tax (PAT) with the Total Assets (TA) of the firm.

Assets Turnover (ATO): It is used to gauge the productivity of the business organisation. It is the efficiency of the firm to convert its input into the output. It is obtained by dividing Net Sales (NS) with the Total Assets (TA) of the organisation. ATO is used as a measure of productivity in many of the previous studies on IC such as Afroz et al. (2018); Firer \& Williams (2003); Mehralian et al. (2012); Ramandeep \& Narwal (2016) and Smriti \& Das (2017).

\section{Control variables}

Three control variables are employed in the study for controlling their effect on the regression models. These are mentioned below:

Size of the firm (LTA): It is computed by the log of Total Assets (TA) of the firm for removing the effect of size on the value creation. The assumption here is that the larger will be the size of the firm more massive will be the benefit from the economies of scale. Log of TA as a proxy of firm's size has been used in the study in line with many 
prominent studies such as Afroz et al. (2018); Al-Musali \& Ku Ismail (2016); Chan (2009a, 2009b) and Sardo et al. (2018).

Physical Capital Intensity (pc): It is figured by dividing Fixed Assets with the Total Assets of the firm. It is employed to remove the effect of fixed assets on value creation. The supposition here is that the fixed assets have a bearing on the value creation of the business organisation. It has been taken in line with many studies on IC such as Firer \& Stainbank (2003); Firer \& Williams (2003); Ghosh \& Mondal (2009); Pal \& Soriya (2012); Smriti \& Das (2018).

Leverage (Lev): It is calculated by dividing the total outside liabilities with the total assets of the firm. It is used to control the effect of debt financing on the company's financial performance. Leverage as a control variable had been included by Smriti \& Das (2017) and Tiwari \& Vidyarthi (2018), among others.

\section{Independent variables}

This empirical work employs the Value Added Intellectual Coefficient (VAIC ${ }^{\mathrm{TM}}$ ) methodology proposed by Pulic (1998) for determining the IC efficiency. The VAIC ${ }^{\mathrm{TM}}$ methodology depends on the postulation that for creating the value, IC needs the support of physical and financial capital (Pulic, 2004). Higher the coefficient of VAIC more will be the creation of value (Pulic, 1998, 2004). Human capital efficiency (HCE), structural capital efficiency (SCE) and capital employed efficiency (CEE) together constitute the $\mathrm{VAIC}^{\mathrm{TM}}$.

Algebraically, $\mathrm{VAIC}{ }^{\mathrm{TM}}=\mathrm{HCE}+\mathrm{SCE}+\mathrm{CEE}$

Human capital efficiency (HCE) shows the addition in the value creation of a firm by an investment of one unit of money on human capital (HC). This one is attained by dividing Value Added (VA) with the HC. 'Total salary and wages' are taken as a proxy for HC (Pulic, 1998, 2004; Ramandeep \& Narwal, 2016).

Structural capital efficiency (SCE) shows the addition in the value creation of the firm by an investment of one unit of money on structural capital (SC). SC encompasses copyright, trademark, patent, systems, database, models and process.SCE is the ratio of SC with the VA. SC is obtained by subtracting HC from VA (Pulic, 1998).

Capital employed efficiency (CEE) shows the addition in the value creation of a firm by an investment of one unit of money on capital employed (CE). It is the ratio of VA with CE.

Algebraically,

1. $\mathrm{HCE}=\mathrm{VA} / \mathrm{HC}$

2. $\mathrm{SCE}=\mathrm{SC} / \mathrm{VA}$

3. $\mathrm{CEE}=\mathrm{VA} / \mathrm{CE}$

Moreover, VA is computed by adding the Depreciation (D) and Amortisation (A), Employee Cost (EC) and Operating Profit (OP) together (Tiwari \& Vidyarthi, 2018). VA is the total value added to the business organisation by utilising all its resources (Nawaz, 2019).

Algebraically,

$\mathrm{VA}=\mathrm{D}+\mathrm{A}+\mathrm{EC}+\mathrm{OP}$

\section{Results and Discussion:- Descriptive statistics:}

Table 1 computes the descriptive statistics of all the variables of the study. These values can be used for crosscountry comparison and also for cross-sector comparison. Table 1 indicates that the average profitability (ROA) of Indian textile industry is only 2.57 per cent, and it varies from minus 69 per cent to plus 32 per cent from one company to another company for the study period 2009-2018. Figure 1 shows the yearly average of ROA of the Indian textile company from the year 2009 to 2018 . Figure 1 indicates that the average ROA of the textile industry varies from two per cent to five per cent except in the year 2017-18, where ROA is negative. The plausible reason for this dent in the profitability of the Indian textile industry maybe because of the announcement of demonetisation of INR 500 and INR 1000 currency notes by the government of India on November 2016. Another reason for this worst performance of the textile industry in the year 2017-18 is maybe because of the implementation of Goods and Service Tax (GST) by the Indian government in July 2017. The in-depth study on the effect of demonetisation and GST on the Indian textile industry may give clear insight which is beyond the scope of this study. 
Table 1:- Descriptive Statistics of all the Variables.

\begin{tabular}{|l|l|c|c|r|r|}
\hline Variables & Size $(\mathrm{N})$ & Mean & Standard Deviation & Minimum & Maximum \\
\hline & & & & & \\
\hline ROA & 1000 & 0.0257 & 0.0764 & -0.6996 & 0.3272 \\
\hline ATO & 1000 & 1.0023 & 0.4713 & 0.0021 & 4.4380 \\
\hline CEE & 1000 & 0.2857 & 0.1515 & 0.0027 & 1.5307 \\
\hline HCE & 1000 & 5.8003 & 4.7308 & 0.2317 & 35.0000 \\
\hline SCE & 1000 & 0.7154 & 0.2995 & -3.3152 & 0.9714 \\
\hline VAIC & 1000 & 6.8015 & 4.8585 & -3.0503 & 36.0793 \\
\hline LTA & 1000 & 2.9376 & 0.4437 & 1.4342 & 4.7340 \\
pc & 1000 & 0.3991 & 0.1670 & 0.0066 & 0.8758 \\
Lev & 1000 & 0.7021 & 0.2599 & & 3.2035 \\
\hline Source: Authors' Compilation
\end{tabular}

The mean of productivity (ATO) shows an excellent average of 1.00 with a range from as low as 0.0021 to as high as 4.44. Among the three constituents of VAIC, it is clear that the significant part of VAIC comes from the HCE with a mean of 5.80 and up to the maximum value of 35. Size of the firm (LTA) has a mean of 2.93 with SD of 0.44 while pc shows an average value of 0.4 with SD of 0.16 . Leverage (Lev) of the Indian textile industry varies from 0.02 to 3.20 , with a mean of 70 per cent, indicating a very high dependency on debt financing. The average VAIC of the Indian textile industry is 6.80. It shows that with every INR 1 invested in the IC efficiency of the textile industry, it creates the value of INR 6.80 .

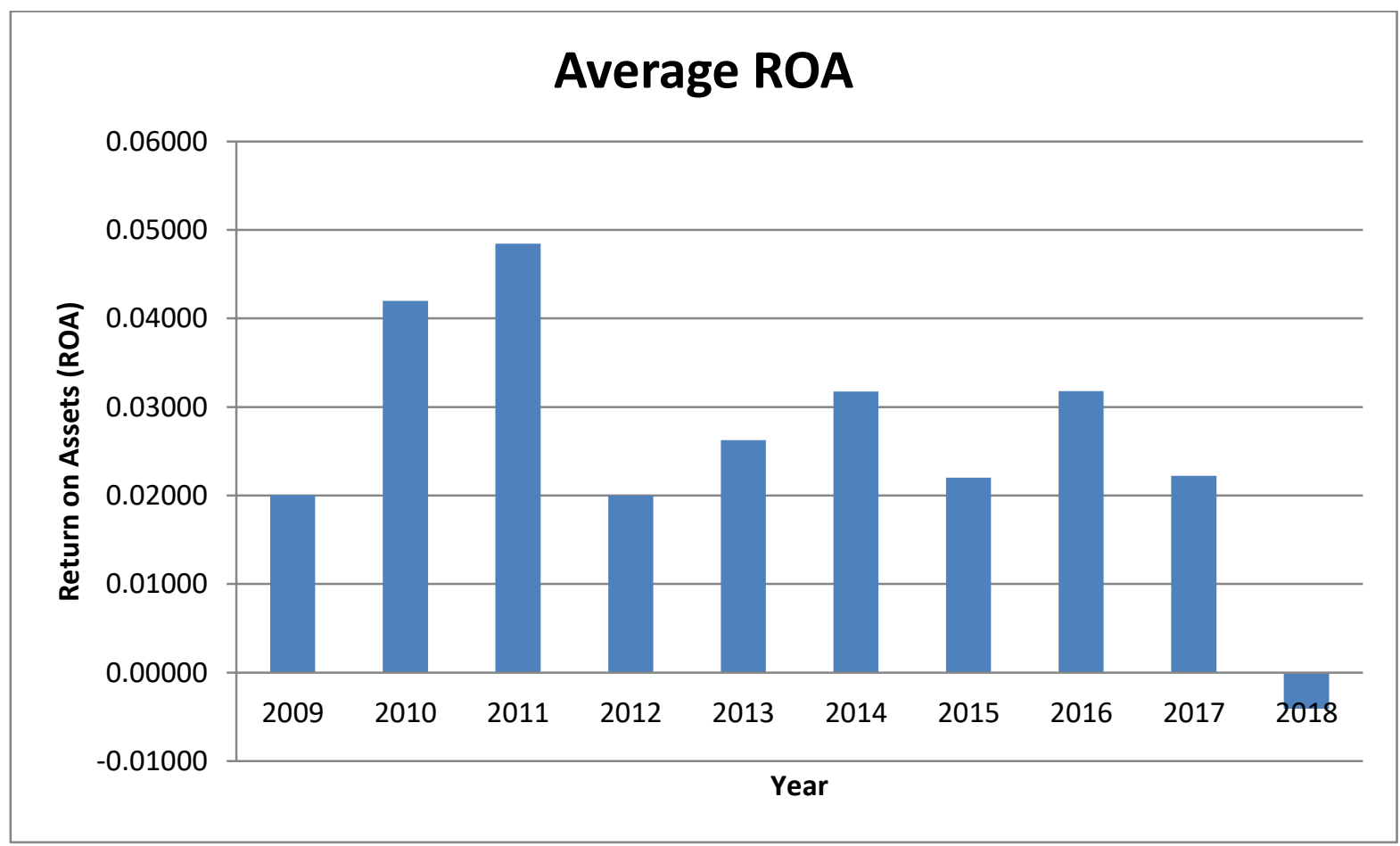

Figure 1:- Yearly Average Return on Assets of the Indian Textile Industry.

Source: Authors' compilation from the data extracted by the "Prowess Database."

\section{Correlation matrix:}

Table 2 displays the outcomes of the correlation matrix for all the variables employed in the analysis. Table 2 illustrates, as anticipated that the VAIC is significantly and positively associated with ROA and ATO. It supports our argument that IC can be employed to boost the financial performance of the Indian textile industry. Besides, the results in Table 2 also revealed that all three components of the IC are positively correlated with ROA and ATO. Furthermore, all the three control variables, i.e. LTA, pc and Lev, are negatively linked with the financial performance, implying that the larger firms, having more fixed assets and higher debt financing are more likely to be less profitable and productive. 
Table 2:- Correlation Matrix.

\begin{tabular}{|c|c|c|c|c|c|c|c|c|c|}
\hline & $\mathrm{ROA}$ & ATO & CEE & HCE & SCE & VAIC & LTA & $\mathrm{pc}$ & Lev \\
\hline ROA & 1.000 & & & & & & & & \\
\hline ATO & $.292 * *$ & 1.000 & & & & & & & \\
\hline CEE & $.444 * *$ & $.375^{* *}$ & 1.000 & & & & & & \\
\hline HCE & $.093 * *$ & $.151 * *$ & $-.139 * *$ & 1.000 & & & & & \\
\hline SCE & $.212 * *$ & $.194 * *$ & $.096 * *$ & $.460 * *$ & 1.000 & & & & \\
\hline VAIC & $.117 * *$ & $.171 * *$ & $-.099 * *$ & $.998 * *$ & $.512 * *$ & 1.000 & & & \\
\hline LTA & $-.153 * *$ & $-.422 * *$ & $-.221 * *$ & -.002 & $-.079 *$ & -.013 & 1.000 & & \\
\hline $\mathrm{pc}$ & $-.144 * *$ & $-.103 * *$ & .025 & -.021 & $.163 * *$ & -.010 & $.093 * *$ & 1.000 & \\
\hline Lev & $-.526 * *$ & $-.167 * *$ & $-.166 * *$ & .050 & $-.077 *$ & .038 & .010 & $.118 * *$ & 1.000 \\
\hline
\end{tabular}

Note: $* *$ and $*$ shows 1 per cent and 5 per cent level of significance respectively.

Source: Authors' compilation

\section{Diagnostic tests:}

4.3.1. Selection of an appropriate model

To select the most appropriate regression model, the authors firstly compared the "pooled OLS model with the fixed-effect model" by applying the F-test, then compared the "pooled OLS model with the random effect model" by using the Lagrange Multiplier test and then finally compared the "fixed effect model with the random effect model" by applying the Hausman test. The results of all these tests are shown in Table 3 . The result in Table 3 shows that, of all the four models, the fixed-effect model is the most suitable regression model for exploring the association between the financial performances of the Indian textile industry with its IC efficiency.

Table 3:- Selection of an Appropriate Model.

\begin{tabular}{|l|c|c|c|c|}
\hline \multicolumn{2}{|l|}{ Model 1 } & Model 2 & Model 3 & Model 4 \\
\hline F test for individual effects & $4.97 * *$ & $3.26 * *$ & $21.73^{* *}$ & $26.80^{* *}$ \\
\hline Lagrange Multiplier test & $230.23^{* *}$ & $115.86^{* *}$ & $1896.15^{* *}$ & $2012.70^{* *}$ \\
\hline Hausman test & $56.58^{* *}$ & $22.87 *$ & $16.92^{* *}$ & $15.31^{*}$ \\
\hline
\end{tabular}

Source: Authors' Compilation

4.3.2. Inspecting the Heteroskedasticity and Auto-correlation in residuals

Breusch-Pagan / Cook-Weisberg test and Wooldridge test were applied for checking the Heteroskedasticity and Auto-correlation in the residuals, respectively. The null hypothesis of the Breusch-Pagan / Cook-Weisberg test is that there is no Heteroskedasticity in residuals while the null hypothesis of the Wooldridge test is that there is no Auto-correlation in residuals. The results of these two tests are shown in Table 4, which show that the null hypothesis of both the tests in all the four models is rejected, confirming the presence of Heteroskedasticity and Auto-correlation in residuals. Hence, the authors report robust standard errors in all the regression models.

\subsubsection{Checking for the multicollinearity}

Variance Inflation Factor (VIF) was employed for testing the problem of multicollinearity in the data. VIF above the value 10 causes the problem of multicollinearity (Gujarati \& Porter, 2010; Pallant, 2010). Since all the values of VIF are below 10 (untabulated), therefore there is no problem of multicollinearity in the data. It can also be verified from the results of the correlation matrix, as shown in Table 2. The maximum correlation among the three independent variables is in between HCE and SCE, i.e. 0.460 and according to Kennedy (1985), correlation exceeding 0.8 will cause the problem of multicollinearity. The correlation between HCE and VAIC is 0.998, but these two variables are not included in the model simultaneously.

Table 4:- Heteroskedasticity and Serial Correlation in Residuals.

\begin{tabular}{|l|c|c|c|c|}
\hline \multicolumn{3}{|l|}{ Model 1 } & Model 2 & Model 3 \\
\hline \multicolumn{3}{|l|}{ Model 4 } \\
\hline Breusch-Pagan / Cook-Weisberg & $727.69 * *$ & $733.08^{* *}$ & $141.47 * *$ & $90.78^{* *}$ \\
\hline Wooldridge test & $7.481^{* *}$ & $5.893^{*}$ & $52.735 * *$ & $41.059 * *$ \\
\hline Note: ** and * shows 1 per cent and 5 per cent level of significance respectively. \\
\hline
\end{tabular}


Source: Authors' Compilation.

Panel regression results:

Table 5 demonstrates the panel data regression results of the study. The regression result of model 1 is shown in Table 5, and this model is used to assess the hypothesis $\mathrm{H} 1$. The results of the regression model 1 show that the efficiency of IC (VAIC) has a significant and positive association with ROA. Thus, the hypothesis H1 is accepted, and therefore, IC can be employed to improve the profitability of the Indian textile companies. The empirical results of this research are consistent with the outcomes of Afroz et al. (2018), Chan (2009a, 2009b), Ghosh \& Mondal (2009) and Ginesti et al. (2018). However, the empirical results of this study are in contrast with the results of Mehralian et al. (2012), Nuryaman (2015) and Ozkan et al. (2017) who shows an insignificant effect of VAIC on ROA.

Table 5:- Regression Results.

\begin{tabular}{|c|c|c|c|c|}
\hline $\begin{array}{l}\text { Models } \longrightarrow \\
\text { Independent } \\
\text { Variables }\end{array}$ & $\begin{array}{l}\text { Model } 1 \\
\text { ROA } \\
\text { FE }\end{array}$ & $\begin{array}{l}\text { Model } 2 \\
\text { ROA } \\
\text { FE }\end{array}$ & $\begin{array}{l}\text { Model } 3 \\
\text { ATO } \\
\text { FE }\end{array}$ & $\begin{array}{l}\text { Model } 4 \\
\text { ATO } \\
\text { FE }\end{array}$ \\
\hline Constant & $\begin{array}{l}0.1394 * \\
(0.0571)\end{array}$ & $\begin{array}{l}0.1314 * * \\
(0.0448)\end{array}$ & $\begin{array}{l}1.6779 * * \\
(0.3730)\end{array}$ & $\begin{array}{l}1.8041 * * \\
(0.2943)\end{array}$ \\
\hline VAIC & $\begin{array}{l}0.0070 * * \\
(0.0015)\end{array}$ & & $\begin{array}{l}0.0082 \\
(0.0063) \\
\end{array}$ & \\
\hline CEE & & $\begin{array}{l}0.1635 * * \\
(0.0424)\end{array}$ & & $\begin{array}{l}1.3627 * * \\
(0.1740)\end{array}$ \\
\hline $\mathrm{HCE}$ & & $\begin{array}{l}0.0042 * * \\
(0.0013)\end{array}$ & & $\begin{array}{l}-0.0043 \\
(0.0053) \\
\end{array}$ \\
\hline SCE & & $\begin{array}{l}0.0324 \\
(0.0347)\end{array}$ & & $\begin{array}{l}-0.0981 \\
(0.0598)\end{array}$ \\
\hline LTA & $\begin{array}{l}-0.0146 \\
(0.0147)\end{array}$ & $\begin{array}{l}-0.0261 * \\
(0.0118)\end{array}$ & $\begin{array}{l}-0.1559 \\
(0.1064)\end{array}$ & $\begin{array}{l}-0.2641 * * \\
(0.0889)\end{array}$ \\
\hline $\mathrm{pc}$ & $\begin{array}{l}-0.0966 * * \\
(0.0348)\end{array}$ & $\begin{array}{l}-0.0943 * * \\
(0.0307)\end{array}$ & $\begin{array}{c}-0.1408 \\
(0.1822)\end{array}$ & $\begin{array}{c}-0.0161 \\
(0.1531)\end{array}$ \\
\hline Lev & $\begin{array}{c}-0.1136^{* *} \\
(0.0356)\end{array}$ & $\begin{array}{c}-0.1223 * * \\
(0.0293)\end{array}$ & $\begin{array}{c}-0.3099 * * \\
(0.1061) \\
\end{array}$ & $\begin{array}{c}-0.4460 * * \\
(0.1017) \\
\end{array}$ \\
\hline $\mathrm{R}^{2}$ & 0.2718 & 0.3351 & 0.0877 & 0.3048 \\
\hline F-stat & $12.57 * *$ & $26.32 * *$ & $3.23 *$ & $16.62 * *$ \\
\hline
\end{tabular}

Notes: ** and * shows 1 per cent and 5 per cent levels of significance respectively; Robust standard errors are shown in the parenthesis. FE shows the fixed-effect model.

In model 2, the components of VAIC are employed as a predictor of ROA, and it is used to test the hypotheses H1a, $\mathrm{H} 1 \mathrm{~b}$ and H1c. The result of model 2 in Table 5 demonstrates that CEE and HCE are significantly and positively related to the profitability (ROA) of the Indian textile firms, while SCE shows an inconsequential effect towards ROA. The empirical results of model 2 failed to accept the hypothesis H1c while accepting the hypotheses H1a and H1b. The results of this research are in line with the outcomes of Al-Musali \& Ku Ismail (2016) and Ozkan et al. (2017) who find a significant association of HCE with ROA; Ginesti et al. (2018) and Mehralian et al. (2012) who demonstrate a significant connexion of CEE with ROA; and Bharathi Kamath (2008) and Nuryaman (2015) who reveal an insignificant effect of SCE on ROA.

In Table 5, the regression result of model 3 reveals that the IC of the Indian textile industry does not have any effect on its productivity (ATO). Model 3 is used to test the hypothesis $\mathrm{H} 2$, and thus the regression results failed to accept the hypothesis H2. The findings of Chan (2009a, 2009b), Ghosh \& Mondal (2009), Ginesti et al. (2018) and Mehralian et al. (2012) also show an insignificant impact of IC on ATO. Nonetheless, the empirical result of this 
study contradicts few of the studies like Mondal \& Ghosh (2012) and Ramandeep \& Narwal (2016) who shows that IC helps in escalating the productivity of the business organisation.

The three constituents of VAIC are employed in model 4 as an explanatory variable of ATO. Model 4 is used to test the hypotheses $\mathrm{H} 2 \mathrm{a}, \mathrm{H} 2 \mathrm{~b}$ and $\mathrm{H} 2 \mathrm{c}$. The regression results of model 4 are shown in Table 5, which reveal that only CEE is significantly and positively influencing the productivity (ATO) of the Indian textile industry while HCE and SCE remain insignificant towards ATO. Therefore, the empirical results failed to support the hypotheses $\mathrm{H} 2 \mathrm{~b}$ and $\mathrm{H} 2 \mathrm{c}$ while accepting the hypothesis H2a. This empirical result supports the finding of Afroz et al. (2018) and Smriti \& Das (2017) who in their paper also confirms that only CEE helps in enhancing the productivity of the firm while HCE and SCE remain inconsequential towards it.

The value of $\mathrm{R}^{2}$ is higher when the VAIC is divided into three components, which show that VAIC constituents are better in explaining the financial performance of the Indian textile industry. Furthermore, from Table 5, it is also clear that ROA should be preferred over ATO for analysing the effect of IC on financial performance as $\mathrm{R}^{2}$ is greater in the case of profitability models than the productivity models.

With regard to the control variables involved in the empirical work, Leverage (Lev) shows a substantial but adverse liaison with the financial performance, confirming that the more use of debt capital decreases the profitability and productivity of the Indian textile industry. Physical capital intensity (pc) has a significant negative relationship only in ROA models (model 1 and model 2), which shows that over-employing the fixed assets inside the firm decreases its profitability. Size (LTA) is significantly negatively associated with ROA and ATO only in model 2 and model 4, respectively, indicating that larger will be the size, lesser will be the profitability and productivity of the business organisation.

\section{Conclusion:-}

As the days are passing on, the competition in the market is becoming harder and stiffer, and the market condition favours the theory of 'survival of the fittest'. Every company needs such type of assets through which it can survive in this storm of fierce competition. Intellectual capital (IC) is one of such assets on which the company can rely upon, not only to survive but also to flourish in this era. This study is an endeavour to fill such a void by scrutinizing the effect of IC on the financial performance of Indian textile industry empirically. As to the best of the authors' knowledge, only minimal studies are conducted on the Indian textile industry.

By adopting the VAIC ${ }^{\mathrm{TM}}$ methodology developed by Pulic (1998), the outcomes of the research reveal that IC efficiency is only noteworthy in enhancing the profitability of the textile firms while for improving the productivity it remains inconsequential. It indicates that companies which are interested in earning enormous profit should increase their attention towards IC. The scenario of Bangladeshi textile sector is in contrast with the scenario of Indian textile industry as the findings of Afroz et al. (2018) exposed that the IC has a significant positive rapport with the productivity of Bangladeshi textile sector.

Amid the constituents of VAIC, capital employed efficiency (CEE) is found to be the utmost significant element in accelerating the financial performance of the Indian textile industry. It validates the fact that the textile firms of India are still largely dependent on the traditional assets, i.e. physical and financial capital for augmenting their financial performance. However, judicious planning should be done in the investment of physical and financial resources as the over-capitalisation may be harmful to the industry.

Human capital enhances the profitability of the textile firms while it fails to improve productivity. Therefore, Indian textile firms should focus on the training and development of their employees, which accelerates their profitability. This, in turn, also enhances the productivity of the employees as adequately trained, and developed employees have higher productivity than the untrained employees. Thus, spending in the development of personnel of the organisation act as an investment, as it is the human, which utilises all the resources of the organisation, whether tangible or intangible. Therefore, the managers and the owners of the firm should arrange proper training and developmental program for their employees, as the expenditure on this training and the developmental program is an investment, it will pay back to the organisation.

From the empirical results of the study, it is also clear that the structural capital of the Indian textile firms is underdeveloped, possibly because of low investment towards the development of the company's SC. The plausible reason for this low investment in SC may be that the majority of these textile firms are undercapitalised, showing an 
inefficiency of the top management. This forces the textile firms to curb their investment in the development of efficient SC and continue to work under the lower quality of SC. Another reason for this insignificant effect of SC on financial performance may be that the majority of the employees are untrained regarding the efficient handling and use of SC. One more important reason is that the textile industry is labour-intensive and therefore the use of a large number of SC like patent, copyright, trademark, among others are irrelevant in this industry.

Furthermore, since India is in the stage of transformation from developing to a developed country, even now the majority of the people are unaware of the importance of these types of intangible assets. They depend more on traditional resources than on modern technology and techniques for flourishing in the market. Therefore, policymaker and managers should create awareness among the employees regarding the importance and benefits of using these types of intangible assets within an organisation.

From the study, it can also be concluded that debt financing should be reduced and proper arrangement for the equity finance should be made. The debt is at an average of 70 per cent, which shows that debt financing is at a very high level, which reduces the profitability and productivity of the Indian textile industry. Proper arrangement and provision should be made to employ the retained earnings and low-cost capital into the organisation instead of using high-cost debt capital.

The results of the remaining variable show that pc is significantly but negatively associated with both the performance indicators, namely, profitability (ROA) and productivity (ATO). This shows that companies having more amounts of fixed assets have lesser ROA and ATO than the companies having lesser fixed assets. While the firm size (LTA) is significant but negatively connected with ROA and ATO, it shows that by decreasing the firm's size, the firm profitability and productivity increases, possibly because the smaller firms efficiently utilise their resources than the larger firms.

The results of the study contribute to the existing literature of IC by confirming empirically that VAIC and HCE significantly and positively influence the profitability of the Indian textile industry. Moreover, CEE can be employed to enhance the firm's profitability and productivity. Also, it provides further insight that investment in structural capital like patents, trademark, databases, process, systems, etc. should be made so that it may escalate the profitability and productivity of the Indian textile industry.

This study may provide help to the policymakers to revive their policies accordingly, and the proper arrangement for the investment in IC like employees' training and development camps, merit-based promotion, rewards for the innovative ideas, investment in the modern systems, software, databases and technology, etc. should be encouraged. The outcomes of this empirical research are subject to several limitations which offer an opportunity for doing further research. Firstly, this study only employs the data of Indian textile companies, so the future work could be extended by doing inter-country or inter-sector comparison analysis. Secondly, there is some inherent limitation of VAIC $^{\mathrm{TM}}$ methodology used in the study, so future studies can be conducted by employing some different IC measurement tool. Thirdly, this study employs the data of only top 100 companies, so further studies can be conducted in future by employing all or majority of the textile companies so that more accurate situation of the Indian textile industry can be estimated.

\section{References:-}

1. Afroz, L., Rana, T., Akter, M., \& Hoque, M. (2018). Impact of intellectual capital on financial performance: evidence from the Bangladeshi textile sector. Journal of Accounting \& Organizational Change, 14(4), 429-454. https://doi.org/10.1108/JAOC-11-2017-0109

2. Al-Musali, M. A., \& Ku Ismail, K. N. I. (2016). Cross-country comparison of intellectual capital performance and its impact on financial performance of commercial banks in GCC countries. International Journal of Islamic and Middle Eastern Finance and Management, 9(4), 512-531. https://doi.org/10.1108/IMEFM-03-2015-0029

3. Bontis, N. (1998). Intellectual capital: An exploratory study that develops measure and models. Management Decision, 2(36), 63-76.

4. Bontis, N. (2001). Assessing knowledge assets: A review of the models used to measure intellectual capital. International Journal of Management Reviews, 3(1), 41-60. https://doi.org/10.1111/1468-2370.00053

5. Bontis, N., Janosevic, S., \& Dzenopoljac, V. (2015). Intellectual capital in Serbia's hotel industry. International Journal of Contemporary Hospitality Management, 27(6), 1365-1384. https://doi.org/10.1108/IJCHM-12-20130541 
6. Cabrita, M. D. R., \& Bontis, N. (2008). Intellectual capital and business performance in the Portuguese banking industry. Int. J. Technology Management, 43(1), 212-237. https://doi.org/10.1504/IJTM.2008.019416

7. Chan, K. H. (2009a). Impact of intellectual capital on organisational performance: An empirical study of companies in the Hang Seng Index (Part 1). The Learning Organization, 16(1), 4-21. https://doi.org/10.1108/09696470910927641

8. Chan, K. H. (2009b). Impact of intellectual capital on organisational performance: An empirical study of companies in the Hang Seng Index (Part 2). The Learning Organization, 16(1), 22-39. https://doi.org/10.1108/09696470910927650

9. Clarke, M., Seng, D., \& Whiting, R. H. (2011). Intellectual capital and firm performance in Australia. Journal of Intellectual Capital, 12(4), 505-530. https://doi.org/10.1108/14691931111181706

10. Dzenopoljac, V., Yaacoub, C., Elkanj, N., \& Bontis, N. (2017). Impact of intellectual capital on corporate performance: evidence from the Arab region. Journal of Intellectual Capital, 18(4), 884-903. https://doi.org/10.1108/JIC-01-2017-0014

11. Edvinsson, L., \& Malone, M. S. (1997). Intellectual capital: Realizing your company's true value by finding its hidden brainpower. New York: HarperCollins.

12. Firer, S, \& Stainbank, L. (2003). Testing the relationship between intellectual capital and a company ' $\mathrm{S}$ performance : Evidence from South Africa University of Natal Durban. Meditari Accountancy Research, 11, 25-44. https://doi.org/10.1108/10222529200300003

13. Firer, Steven, \& Williams, M. S. (2003). Intellectual capital and traditional measures of corporate performance. Journal of Intellectual Capital, 4(3), 348-360. https://doi.org/10.1108/14691930310487806

14. Ghosh, S. K., \& Maji, S. G. (2015). Empirical Validity of Value Added Intellectual Coefficient Model in Indian Knowledge-based Sector. Global Business Review, 16(6), 947-962. https://doi.org/10.1177/0972150915597597

15. Ghosh, S., \& Mondal, A. (2009). Indian software and pharmaceutical sector IC and financial performance. Journal of Intellectual Capital, 10(3), 369-388. https://doi.org/10.1108/14691930910977798

16. Ginesti, G., Caldarelli, A., \& Zampella, A. (2018). Exploring the impact of intellectual capital on company reputation and performance. Journal of Intellectual Capital, 19(5), 915-934. https://doi.org/10.1108/JIC-012018-0012

17. Gogan, L. M., Artene, A., Sarca, I., \& Draghici, A. (2016). The Impact of Intellectual Capital on Organizational Performance. Procedia - Social and Behavioral Sciences, 221(0), 194-202. https://doi.org/10.1016/j.sbspro.2016.05.106

18. Gujarati, D. N., \& Porter, D. C. (2010). Basic Econometrics (5th Editio). New York: McGraw-Hill/Irwin.

19. Hashim, M. J., Osman, I., \& Alhabshi, S. M. (2015). Effect of Intellectual Capital on Organizational Performance. Procedia - Social and Behavioral Sciences, 211(September), $207-214$. https://doi.org/10.1016/j.sbspro.2015.11.085

20. ibef. (2019). Textile Industry \& Market Growth in India. Retrieved July 29, 2019, from https://www.ibef.org/industry/textiles.aspx

21. India, M. in. (2018). TEXTILES AND GARMENTS. Retrieved July 29, 2019, from http://www.makeinindia.com/sector/textiles-and-garments

22. Joshi, M., Cahill, D., Sidhu, J., \& Kansal, M. (2013). Intellectual capital and financial performance: An evaluation of the Australian financial sector. Journal of Intellectual Capital, 14(2), 264-285. https://doi.org/10.1108/14691931311323887

23. Kamath, G. B. (2008). Intellectual capital and corporate performance in Indian pharmaceutical industry. Journal of Intellectual Capital, 9(4), 684-704. https://doi.org/10.1108/14691930810913221

24. Kennedy, P. (1985). A Guide to Econometrics (2nd ed.). MIT Press, Cambridge, MA.

25. Mehralian, G., Rajabzadeh, A., Sadeh, M. R., \& Rasekh, H. R. (2012). Intellectual capital and corporate performance in Iranian pharmaceutical industry. Journal of Intellectual Capital, 13(1), 138-158. https://doi.org/10.1108/14691931211196259

26. Mondal, A., \& Ghosh, S. K. (2012). Intellectual capital and financial performance of Indian banks. Journal of Intellectual Capital, 13(4), 515-530. https://doi.org/10.1108/14691931211276115

27. Nawaz, T. (2019). Intellectual capital profiles and financial performance of Islamic banks in the UK. International Journal of Learning and Intellectual Capital, 16(1), 87-97.

28. Nazari, J. A., \& Herremans, I. M. (2007). Extended VAIC model: measuring intellectual capital components. Journal of Intellectual Capital, 8(4), 595-609. https://doi.org/10.1108/14691930710830774

29. Nuryaman. (2015). The Influence of Intellectual Capital on The Firm's Value with The Financial Performance as Intervening Variable. Procedia - Social and Behavioral Sciences, 211(September), 292-298. https://doi.org/10.1016/j.sbspro.2015.11.037 
30. Ozkan, N., Cakan, S., \& Kayacan, M. (2016). Intellectual capital and financial performance: A study of the Turkish Banking Sector. Borsa Istanbul Review, 17(3), 190-198. https://doi.org/10.1016/j.bir.2016.03.001

31. Pal, K., \& Soriya, S. (2012). IC performance of Indian pharmaceutical and textile industry. Journal of Intellectual Capital, 13(1), 120-137. https://doi.org/10.1108/14691931211196240

32. Pallant, J. (2010). Survival Manual. Berkshire: Mc Graw Hill.

33. Poh, L. T., Kilicman, A., \& Ibrahim, S. N. I. (2018). On intellectual capital and financial performances of banks in Malaysia. Cogent Economics \& Finance, (6), 1-15. https://doi.org/10.1080/23322039.2018.1453574

34. Pulic, A. (1998). Measuring the performance of intellectual potential in the knowledge economy. The 2nd" World Congress on the Management of Intellectual Capital", 1-20.

35. Pulic, A. (2004). Intellectual capital - does it create or destroy value? Measuring Business Excellence, 8(1), 6268. https://doi.org/10.1108/13683040410524757

36. Ramandeep, \& Narwal, K. P. (2016). Investigating the impact of intellectual capital on financial performance in Indian manufacturing sector. JIMS8M: The Journal of Indian Management \& Strategy, 21(4), 28. https://doi.org/10.5958/0973-9343.2016.00030.2

37. Riahi-belkaoui, A. (2003). Intellectual capital and firm performance of US multinational firms A study of the resource-based and stakeholder views. Journal of Intellectual Capital, 4(2), 215-226. https://doi.org/10.1108/14691930310472839

38. Saint-Onge, H. (1996). Tacit knowledge: the key to the strategic alignment of intellectual capital. Strategy \& Leadership, 24(2), 10-16.

39. Sardo, F., \& Serrasqueiro, Z. (2017). A European empirical study of the relationship between firms' intellectual capital, financial performance and market value. Journal of Intellectual Capital, 18(4), 771-788. https://doi.org/10.1108/JIC-10-2016-0105

40. Sardo, F., Serrasqueiro, Z., \& Alves, H. (2018). On the relationship between intellectual capital and financial performance: A panel data analysis on SME hotels. International Journal of Hospitality Management, 75(September), 67-74. https://doi.org/10.1016/j.ijhm.2018.03.001

41. Scafarto, V., Ricci, F., \& Scafarto, F. (2016). Intellectual capital and firm performance in the global agribusiness industry: The moderating role of human capital. Journal of Intellectual Capital, 17(3), 530-552. https://doi.org/10.1108/JIC-11-2015-0096

42. Singh, S., Sidhu, J., Joshi, M., \& Kansal, M. (2016). Measuring intellectual capital performance of Indian banks: A public and private sector comparison. Managerial Finance, 42(7), 635-655. https://doi.org/10.1108/MF-08-2014-0211

43. Smriti, N., \& Das, N. (2017). Impact of Intellectual Capital on Business Performance: Evidence From Indian Pharmaceutical Sector. Polish Journal of Management Studies, 15(1), 232-243. https://doi.org/10.17512/pjms.2017.15.1.22

44. Smriti, N., \& Das, N. (2018). The impact of intellectual capital on firm performance: a study of Indian firms listed in COSPI. Journal of Intellectual Capital, 19(5), 935-964. https://doi.org/10.1108/JIC-11-2017-0156

45. Stewart, T. A. (1997). Intellectual Capital: The New Wealth of Organizations. New York: Nicholas Brealey Publishing Limited.

46. Sydler, R., Haefliger, S., \& Pruksa, R. (2014). Measuring intellectual capital with financial figures: Can we predict firm profitability? European Management Journal, 32(2), 244-259. https://doi.org/10.1016/j.emj.2013.01.008

47. Tan, H. P., Plowman, D., \& Hancock, P. (2007). Intellectual capital and financial returns of companies. Journal of Intellectual Capital, 8(1), 76-95. https://doi.org/10.1108/14691930710715079

48. Tiwari, R., \& Vidyarthi, H. (2018). Intellectual capital and corporate performance: a case of Indian banks. Journal of Accounting in Emerging Economies, 8(1), 84-105. https://doi.org/10.1108/JAEE-07-2016-0067

49. Weqar, F., \& Haque, S. M. I. (2020). Intellectual capital and corporate financial performance in India's central public sector enterprises. International Journal of Learning and Intellectual Capital, 17(1), 77-97. https://doi.org/10.1504/IJLIC.2020.105323

Xu, J., \& Wang, B. (2018). Intellectual Capital, Financial Performance and Companies' Sustainable Growth: Evidence from the Korean Manufacturing Industry. Sustainability, 10, 1-15. https://doi.org/10.3390/su10124651

50. Zeglat, D., \& Zigan, K. (2013). Intellectual capital and its impact on business performance: Evidences from the Jordanian hotel industry. Tourism and Hospitality Research, 13(2), 83-100. https://doi.org/10.1177/1467358413519468. 